\title{
Assessing Core Didactic Competencies of Pre-service English Language Teachers During Practicum: A European Perspective
}

\author{
Dr. Haggag Mohamed Haggag \\ Lecturer of Curricula \& TEFL Methodology Hurghada Faculty of Education \\ South Valley University, Egypt
}

Doi:10.19044/esj.2018.v14n17p12 URL:http://dx.doi.org/10.19044/esj.2018.v14n17p12

\begin{abstract}
This research discusses implementing a European document (European Portfolio of Student Teachers of Language EPOSTL) as a selfassessment tool. The research design experiments the European portfolio for pre-service language teachers (EPOSTL), which has been translated by the researcher and published by the Council of Europe. The portfolio is used with the aim of assessing the key teaching competencies of pre-service English language teachers during the teaching practice or the practicum. The paper examines key 5 descriptors of didactic competencies in the EPOSTL which are (Lesson planning- Conducting a lesson- classroom managementIndependent learning- Assessment of learning). It highlights implementing the portfolios as means of assessing the competencies of language teachers in pre-service context. Instruments of the research include EPOSTL, teaching competence scale and portfolio assessment rubric. Results of implementing the portfolio on a sample of (N. 30) students at Hurghada Faculty of Education during their practicum (3 groups in 3 official language schools) are reported. The results indicate that using EPOSTL as a self-assessment tool has positive impacts on developing the five areas of the portfolio as measured by the Teaching Competencies Scale (TCS) designed by the researcher. The scale includes the main areas of the EPOSTL to be examined by the students while the fifth area "classroom management" was included as in the EPOSTL with "conducting a lesson" area. The recommendations include: implementing the electronic portfolios as self-assessment tools, the need for assessing didactic competencies using authentic assessment tools and designing valid and reliable tools of assessing the whole teaching practice or "practicum" of pre-service English language teachers.
\end{abstract}

Keywords: EPOSTL - Practicum - Competencies 


\section{Introduction}

Assessment and learning are one; they both interrelate to achieve a better educational setting. Best assessment practices aim to promote learning as well as assessment. Lam (2016, p.1) asserts that "from mid-1990s, assessment for learning AFL has been extensively promulgated for enhancing teaching and learning within various school and university contexts, as opposed to assessment of learning AOL which aims to judge learning for the purpose of certification". Despite the formative potential of AFL, to promote these practices various assessment tools such as tests, quizzes and portfolios are used to coin both learning and assessment.

Portfolios have been used in various frameworks to stimulate both reflection and developing different skills. They are divided into teacher portfolios and student portfolios; they can be in electronic or paper formats and both formats can be used for reflection and assessment purposes. In this research a paper teacher portfolio is targeted and used as a reflective and assessment tool. According to (Dineke, 2006), the first introduction of the portfolios was in 1970s. They are used to stimulate reflection on teaching and to emphasize behaviors and competencies. Korthagen (2004, p. 80) presented the following framework for reflection during teaching:

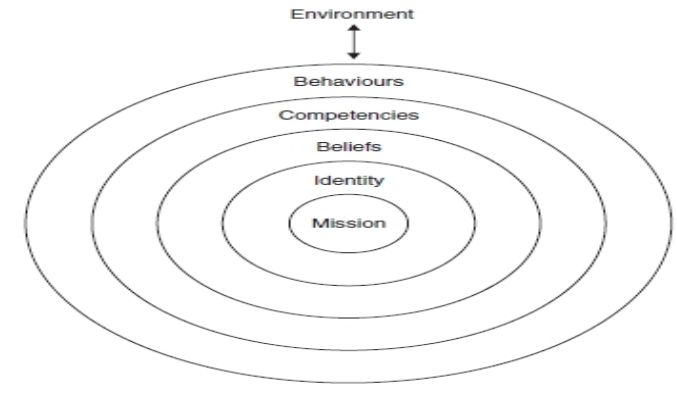

Figure (1) Korthagen (2004) Teacher reflection

In the above figure, Beliefs refers to teacher perceptions, identity, refers to teaching approaches while mission is concerned with aims and goals. The above process of reflection aims to develop competencies and behaviors in a distinctive environment. Portfolios can be used not only for reflection but as assessment tools in various contexts including pre-service teacher education.

Teacher education programs should integrate assessment portfolios for the purpose of improvement. For instance, Strudler \& Wetzel (2012, p. 163) expressed the view that "in assessment portfolios, standards and evaluation rubrics provide direction for artifact selection and organization of the ESP. Students create these portfolios to satisfy outside readers, 
mentors or reviewers. Colleges of education aggregate and disaggregate the evaluation data to demonstrate that teacher candidates within the program are meeting the necessary standards. They also use the data to inform where improvements may be required". For instance, Land \& Zemabl Soul (2003) stressed that portfolios help pre-service teachers to document and explore principles of light. They can be used for analysis of previous work and new experiences as well as for mentoring purposes. Assessment portfolios follow guidelines and standards that cope with the targeted competencies in a teacher preparation program.

This research attempts to use a European portfolio for both the reflective and assessment purposes. The European Portfolio for Student Teachers of Languages (EPOSTL) is a document by the Council of Europe and The European Center of Modern Languages ECML in (2007). The key descriptors of didactic competencies in EPOSTL, which are tracked in the present research, are (Lesson planning- Conducting a lesson- Classroom management- Independent learning - Assessment of learning). In this research EPOSTL is used as a reflective assessment tool during practicum in an EFL context.

\section{Theoretical Framework}

This literature review discusses portfolios as assessment reflective tools, EPOSTL as the key assessment tool utilized in the research, a description for practicum in Egyptian teacher education programs and finally a discussion of competency and teaching competencies is presented.

\section{Portfolios}

Portfolios in education were firstly introduced in late 1980s (Hoxha \& Tafani: 2015) to function and achieve various goals and objectives with their different components. For instance they can be used for assessing learning (Assessment Of Learning AOL) or they are used to promote learning (Assessment Of Learning AOL). They can be in a paper form like the type of portfolios used in this research or they can be electronic "eportfolios". Portfolios have mainly five features as identified by Janssens, Boes \& Wante (2002); the first it is a collection of artifacts by the students. Second, it is a learner's responsibility to document his portfolio. Third, it is an illustration of student development. Fourth, it should include a reflection section to complete the meaning of the collected content. To sum up, the portfolio is a coaching tool to develop the student's skills. These features mark any portfolio whether a paper or electronic one, a student or a teacher portfolio. Portfolios have many advantages and benefits for skills development. 
There are many benefits for the portfolios in both foreign language education and teacher education regardless of their limitations. Huang (2012, p. 1) stated that "using portfolios in foreign language education have lots of benefits: offering a multi-dimensional perspective of student progress over time, promoting self-reflection and learner autonomy and integrating learning, teaching and assessment". Portfolios help teachers to gain insights about the learners and about their own skills' development. They are effective instruments for both learning and assessment as well regardless of their shortcomings in their application in large classes, time consumption and their use as summative assessments instruments rather than informative practices. These advantages vary according to the type of the portfolio. Barret (2002) argues that the portfolio as an adjective describes its purposes; these purposes include learning, assessment, best work, marketing and employment portfolio. In this research, the portfolio is used as an assessment tool for assessing student teacher's didactic or teaching competences.

Portfolios have long been used for purposes of learning as well as assessment. For instance, Cain (2005, p.79) highlights the use of portfolios as assessment tools for both product and process assessments. She states that "Portfolios capture both the product and process of assessment tasks. The product assessment is represented in the actual documentation of accomplishment and the progress related to specific competencies (the evidence). The process encompasses the dynamic activities of production, collection, selection, reflection, and projection, which are critical to the construction of the portfolio". Shackelford (1996, p. 31) stresses that "as assessment tools, portfolios are an integral element of "authentic" and "performance" assessment systems for enhancing and evaluating hard to measure skills. Unlike traditional forms of assessment designed to evaluate isolated facts and skills, portfolios effectively, efficient and meaningfully capture student learning over time and across disciplines". Portfolios can be used for the purposes of performance-oriented assessment not only for product oriented assessments. They tend to track the whole performance not only the final product. One of the important portfolios that were used in teacher education programs in many countries in Europe and Asia for various purposes is the EPOSTL. Following is a description for this portfolio.

\section{EPOSTL}

The European Portfolio for Student Teachers of Languages (EPOSTL) is a document by the Council of Europe and The European Center of Modern Languages ECML in 2007 in both English and French languages. It was translated into (11) different languages and the author translated the Arabic version. According to Newby (2011), one of its authors, EPOSTL is a 
didactic portfolio which targets the pre service teachers (student teachers). It helps them to prepare for future teaching profession with the framework of reflection they have during their practicum. The portfolio is a valid self reflection and assessment tool.

The EPOSTL has many five main aims in its four main contents (EPOSTL: 2007). First is to encourage student teachers to reflect on their competences. Second is to help students to prepare for future profession. Third is to promote discussions with peers, teachers and mentors. Fourth is to facilitate self-assessment of the developing competences. Fifth is to provide an instrument that charts progress. These aims can be achieved through the six contents of the EPOSTL. The first is the personal statement where student teachers reflect on their teaching philosophy. The second is selfassessment where students use can do descriptors. The third is a dossier to provide evidence and examples of work. The fourth is a glossary of terms used in teaching and learning. The fifth is the index of terms used in the descriptors. The sixth is the user's guide which gives details about the EPOSTL.

The EPOSTL has covered a gap in addressing four main competencies (language/cultural competence, learner's competence, student teachers' competencies and teacher education). The following figure (2) clarifies the position of EPOSTL in the European education and policy (Newby: 2011).

Figures (2): EPOSTL and the European Education documents

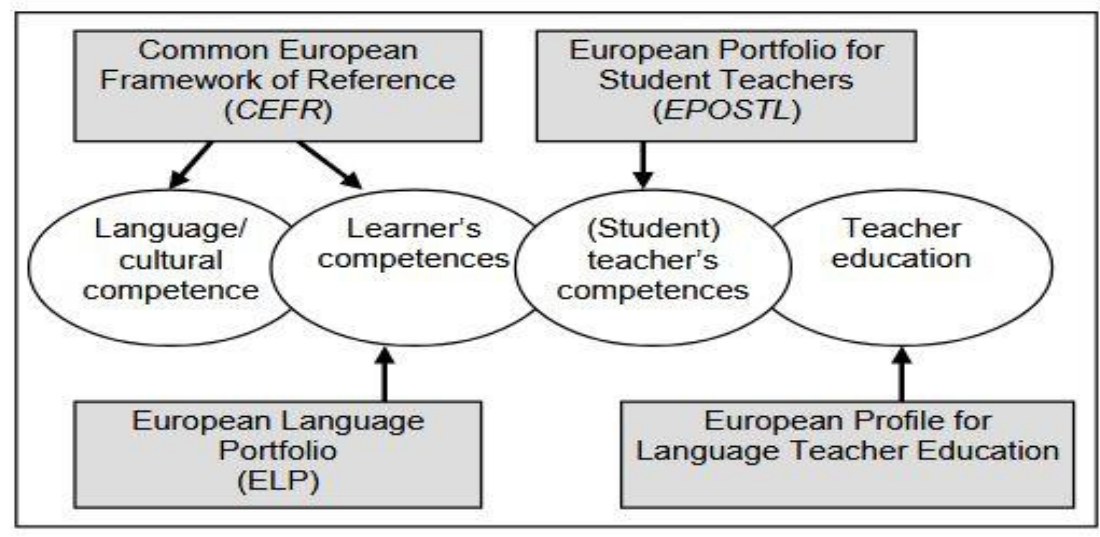

The above figure (2) relates EPOSTL to the constitution that governs the European education names Common European Framework of Reference CEFR and other documents as ELP and EPLTE. It is a key document that can be mainly used in a pre-service context compared another document EPLTE that can be used in an in service context. The figure shows why and how the EPOSTL was used in Europe. The above figure also knows that 
these elements can be examined in other European contexts since the processor layer (student-teacher) is not culture-oriented.

\section{Practicum}

Practicum or teaching practice is an essential important part of any teacher education system and it is valued by the student teachers as well (Wilson: 2006, Beck \& Kosnik: 2002). In the Egyptian context, student teachers do their practicum in the last two years of their first degrees and in some post-graduate programs as well. They are assigned in group that vary to the maximum of 10 students and are assigned to a mentor from the school and to another from the university. They spend these 4 semesters teaching the courses of their schools they are in with the help of their supervisors and mentors. The practicum in Egypt is a compulsory course for students to attend regularly to pass; otherwise they fail the whole academic year. This explains why it is very important to students' academic degree and future career besides the value it adds to their teaching skills.

The practicum or teaching practice stems from the early ideas by Dewy (1938) which view experience as a key element for a real learning. It also relays on Vygotsky (1986) views about exposing the learner to challenges that go beyond his current level of competence. There are various views about what a good practicum is (see Hammond: 2013\&Ulvik \& Smith 2011). One of the comprehensive listing for a high quality practicum program is that by Eyers (2005) who viewed a good practicum integrates theoretical knowledge with practice. It also should be based on cooperation and partnership between teacher education institutions and schools. It also should follow clear progressive stages for teacher development. It should follow effective assessments and evaluations for goals, resources, needs and implications. A combination of on-campus and in-school units and modules should be articulated. The well selected school mentors should also initiate writing effective reports about student teachers' performance. These qualities may guarantee an effective practicum

\section{Didactic competencies}

This research adopts the term "competency" to include the "competence" in teaching since they are interrelated and refer to "mastery or skill" but in different contexts. Although interchangeable, the term competence refers to the cognition "knowledge" that we have in mind, while competency refers to the ability to perform tasks. Kianna (2018, p.1) expresses the difference in terms of skills "Competencies are the skills a person have that fulfill some requirement. Competence is a person's overall ability to fulfill those requirements. It can also mean a sustainable income, though that is not found very often today, and they do have different 
technical meanings". A general definition for competency was presented by (Tigelaar et al. (2004) to mean the level of integration of knowledge, skills, and attitudes.

Since competency was used in literature to refer to performance, which is the core of this research, the research uses the term competency to mean the different competences that should be mastered and performed by the pre service teachers as identified by EPOSTL.

The concept of competence is perceived in many aspects. Newby (2011, p. 15) argued that three hypotheses can be perceived about competence:

"The first is the widespread acceptance that language is essentially a cognitive phenomenon and that the use of the linguistic code of a language (performance).... The second is the recognition that the subject of linguistic description is not only the mental processes that steer language but the speech community and culture .... The third is that language analysis must include not only the systems and rules but also language use."

Competence has also been compared with "performance" in both language skills as well as pedagogical skills (see Tomasello (2003), Robinson \& Ellis (2008) and Hole (2009)). Newby (ibid, 25) expresses the view that "the scope of competences described in the Common European Framework of Reference CEFR extends beyond the merely cognitive, linguistic and functional to include general competencies which are based on the potential of a school language learning environment to provide a framework in which personal, social and culture competences can be enhanced". Due to this significant impact of the different "competencies "that teachers should master, the European Portfolio for Student Teachers of Languages was designed to track these competences.

\section{European Portfolio for Student Teachers of Languages EPOSTL:}

EPOSTL has 295 descriptors that are regarded as core teaching competencies which language teachers strive to attain. These descriptors have to be reflected over different periods of times and stages during the practicum (ibid).Student teachers can color the bar of competence according to their assessments. A bar like in figure (3) should be similar to final descriptor completion.

Figure (3): Example descriptor from EPOSTL

I can create a supportive atmosphere that invites learners to take part in speaking activities.

\begin{tabular}{l|l|l}
6.3 .06 & 24.10 .06 & 18.1 .07
\end{tabular}


The figure shows the systematic and clear tracking of the competencies tracking is. Student teachers write the dates of their reflection as shown above. The figure also shows that the above competence or descriptor responses still need more time to be complete and to show mastery. This example shows how EPOSTL reflects the idea that becoming a good teacher is a long life process. The research follows EPOSTL key descriptors of didactic competencies. These competencies are lesson planning, conducting a lesson, independent learning, and assessment of learning. In this research, these competencies are reflected, tracked and developed.

Karimi (2014, p.3) views the didactic competencies as "an integration of professional knowledge, skills and attitudes to enable \{teachers $\}$ to do their roles and effectively influence the students' learning process". $\mathrm{He}$ argues that there are three main competencies in literature; the first is professional attitudes, second are the didactic competencies and finally subject matter competences. He further argues that teaching competencies are results of integration between knowledge, skills and attitudes. In her study, Paisi (2014) examined the didactic competences of primary schools teachers. These competencies include specialty competencies (such as familiarity with the scientific content), psycho-pedagogic competencies (as recognizing students' profile) and socio-managerial competences (such as students' organization and group cooperation). These competencies are also included in the various descriptors of EPOSTL.

\section{Research Hypotheses}

3.1. There are statistically significant mean differences between participants' mean scores of the participants on the core didactic competencies scale favoring the post application.

3.2. There are no statistically significant mean differences between the mean scores of the participants in the pre-post application on EPOSTL assessment rubric.

\section{Method}

The research followed the quasi-experimental design, where participants were exposed to an independent variable (EPOSTL) and then pre post tests were run. Mean differences were compared using SPSS program for both the didactic competencies scale's results and for portfolio rubric scores as well. 


\section{Participants}

Number of (30) students from the fourth year English majors education at Hurghada Faculty of Education were randomly selected in the experiment during their teaching practicum course. Their practicum was at the academic year 2016/2017 (3 groups (10 students each) in 3 official language schools at Hurghada Administration, Red Sea Governorate). They were homogeneously adjusted according to grade (fourth year major education), specialization (English), and school type (practicum at official schools only). Participants were informed to complete the EPOSTL before they use it (pre testing) to identify their prior knowledge and to adjust their teaching competencies before the experiment.

\section{Instruments}

The research utilizes the following three instruments:

3.2.1. The European Portfolio for Student Teachers of Languages EPOSTL, designed by The Council of Europe and The European Center for Modern Languages in Austria (Didactic Competencies section that includes lesson planning - conducting a lesson- Methodology- classroom management- assessment of learning ).

3.2.2. Core Didactic competencies scale of pre service English language teachers, designed by the researcher. It includes (50) items in the light of the five sections in the EPOSTL portfolio. The scale was validated by a jury of TEFL experts. They reported its content validity to achieve its aims.

3.2.3. Portfolio assessment rubric, designed by the researcher. It aims as assessing the participants' progress over EPOPSTL portfolio. It includes indicators for assessing the areas of EPOSTL portfolio. Content validity was calculated to the rubric. The jury agreed on the following domains of the rubric (lesson - conducting a lesson and "classroom management"Methodology- assessment of learning). They recommended adding classroom management to conducting a lesson domain.

\section{Delimitations}

The research was delimited to (30) pre service student teachers at Hurghada Faculty of Education, English majors department. It was also delimited to the five didactic competencies at the EPOSTL which are (lesson planning - conducting a lesson- Methodology- classroom managementassessment of learning). As to place, the experiment was conducted at Hurghada administration, Red Sea Governorate, Egypt. The experiment was delimited to a number of 3 groups with a total number of 30 students from an official language school, Hurghada administration, Red Sea, Egypt. 


\section{Design}

The participants (30) from fourth year English majors department were randomly selected to participate in the experiment. They were encouraged to use the self-reflection tool which will help them to track their teaching skills development. Students received a free course from the languages and research center at the college to encourage them participate in the experiment for a whole academic year from $10^{\text {th }}$ of October (2016) till $10^{\text {th }}$ of May (2017). Students were first introduced with EPOSTL in a workshop by the researcher at College Language Center and were handed the EPOSTL. They were acquainted with its sections and trained on how to complete its descriptors. They were exposed during the workshop to good and bad practices for portfolio completion. They were informed about its objective as a tracking tool and assessment tool as well for their teaching development. They were also informed that the aim behind this experiment is to help them track their progress and determine their core teaching skills' development and is not a grade consideration tool like tests and exams. Three mentors from the participating schools attended the workshop and were acquainted with how to track the participants' progress and mentor their development. Participants agreed on the following schedule for the experiment.

Table (1): EPOSTL scope and sequence during practicum including assessment plan

\begin{tabular}{|c|c|c|c|}
\hline $\mathrm{y}$ & Month & Content area / EPOSTL & Assessments \\
\hline Sat. $8^{\text {th }}$ & October 16 & Preliminary workshop and leading in. & Sampling / 30 \\
\hline \multirow[t]{2}{*}{ Thu. $13^{\text {th }}$} & October 16 & First day (Area one planning a lesson" & -Self-reflection \\
\hline & Nov. 2016 & Planning and methodology & -Self-reflection \\
\hline \multirow[t]{2}{*}{ Thu. 22nd } & Dec. 2016 & $\begin{array}{l}\text {-To complete area } 2 \text { conducting a lesson. } \\
\text {-Meeting with mentor }\end{array}$ & $\begin{array}{l}\text {-Mentor meeting } \\
\text {-Researcher meeting }\end{array}$ \\
\hline & January & Semester break and exams & \\
\hline \multirow[t]{3}{*}{ Thu. $16^{\text {th }}$} & Feb. 2017 & -To complete area 3 Methodology & -Self-reflection \\
\hline & March 2017 & -To complete area 4 classroom management & -Self-reflection \\
\hline & April 2017 & $\begin{array}{c}\text {-To complete area } 5 \text { Assessment of } \\
\text { Learning }\end{array}$ & -Self-reflection \\
\hline Thu. $27^{\text {th }}$ & April 2017 & $\begin{array}{l}\text {-To complete missing areas } \\
\text {-Meeting with mentor }\end{array}$ & $\begin{array}{c}\text {-Self-reflection } \\
\text {-Mentor meeting }\end{array}$ \\
\hline Thu. $11^{\text {th }}$ & & -Final meeting / Reports / copy portfolio & -Researcher/mentor \\
\hline
\end{tabular}

Following the above schedule, students were acquainted with domains to complete in EPOSTL, how to complete it and what procedures to follow after its completion. Students were informed about the start and end dates as well as training days which were on the last day of the week due to college procedures and schools vacancy, in their timetables. 


\section{Findings and discussion}

Results of this research were mainly obtained from two instruments that answer the two research hypotheses. Using SPSS statistical program the following results were obtained to answer the research hypotheses.

6.1. There are statistically significant mean differences between participants' mean scores of the participants on the core didactic competencies scale favoring the post application

To answer this hypothesis, a validated didactic competencies scale for pre service English language teachers was designed by the researcher. The questionnaire was applied before and after the application of EPOSTL. Means were compared after encoding responses using a scale from 1-5, then, total responses were summed (Sum. 150). The following table (2) indicates the descriptive statistics of the obtained results. It shows the differences in means in the two tests for the pre and posttests (89 and 105.10) respectively. Table (2): Descriptive Statistics

\begin{tabular}{|c|c|c|c|c|}
\hline Statistics & $\mathrm{N}$ & Mean & Std. Deviation & $\begin{array}{c}\text { Std. Error } \\
\text { Mean }\end{array}$ \\
\hline Pre scale & 30 & 89.00 & 10.485 & 1.914 \\
& 30 & 105.10 & 11.330 & 2.069 \\
\hline
\end{tabular}

Table (2) indicates that the scores are greater in the final testing and there is a development in their teaching competencies as shown in participants' means. To identify whether this difference in means is significant or not the following treatment was statistically run as table (3) indicates below.

Table (3) Comparing means

\begin{tabular}{|c|c|c|c|c|c|c|}
\hline \multirow{3}{*}{ Statistics } & \multicolumn{6}{|c|}{ Test Value $=0$} \\
\cline { 2 - 7 } & $\mathrm{T}$ & $\mathrm{DF}$ & Sig. (2-tailed) & $\begin{array}{c}\text { Mean } \\
\text { Difference }\end{array}$ & \multicolumn{2}{c|}{$\begin{array}{c}\text { 95\% Confidence } \\
\text { Interval of the } \\
\text { Difference }\end{array}$} \\
\cline { 2 - 8 } & Lower & Upper & Lower & Upper & Lower & Upper \\
\hline Pre scale & 46.493 & 29 & .001 & 89.000 & 85.08 & 92.92 \\
& 50.808 & 29 & .001 & 105.100 & 100.87 & 109.33 \\
\hline
\end{tabular}

Table (3) shows that comparing the two means resulted significant differences at level (0.05) as the shaded areas in the table show. These significant differences in means show that participants' core didactic competences had developed greatly due to the use of the independent variable which is EPOSTL. This also shows that the five basic teaching competences (lesson planning, methodology, classroom management, 
conducting a lesson and assessment of learning) can be developed if portfolio is effectively used following the steps of the experiment to assess these competences. How did the research assess the portfolio? The answer to this question is included in the following hypothesis.

\subsection{There are no statistically significant mean differences between the mean} scores of the participants in the pre-post application on EPOSTL assessment rubric.

To answer the above hypothesis, a portfolio assessment rubric instrument was designed by the researcher to assess EPOSTL responses by participants. It includes indicators for assessing the teaching competencies in EPOSTL portfolio. Responses of the participants were encoded using a scale from 1-3 with a total of 100 marks for the whole responses. Then, following a pre post analysis using SPSS the following descriptive data were obtained.

Table (4): Descriptive Statistics

\begin{tabular}{|c|c|c|c|c|}
\hline Statistics & $\mathrm{N}$ & Mean & Std. Deviation & $\begin{array}{c}\text { Std. Error } \\
\text { Mean }\end{array}$ \\
\hline Pre-rubric & 30 & 46.80 & 8.692 & 1.587 \\
& 30 & 62.87 & 16.298 & 2.976 \\
\hline
\end{tabular}

The above table (4) shows the difference in means obtained from the rubrics and that the greater mean goes for post application (62.87) compared to (46.80) for the pre testing. This difference in means was analyzed statistically to verify if it is significant or not. The following table (5) shows the results of this analysis.

Table (5): Comparing means

\begin{tabular}{|c|c|c|c|c|c|c|}
\hline \multirow{3}{*}{ Statistics } & \multicolumn{6}{|c|}{ Test Value = 0 } \\
\cline { 2 - 7 } & Lower & Upper & Lower & Upper & \multicolumn{2}{c|}{$\begin{array}{c}\text { 95\% Confidence } \\
\text { Interval of the } \\
\text { Difference }\end{array}$} \\
\cline { 2 - 7 } & tailed) & $\begin{array}{c}\text { Mean } \\
\text { Difference }\end{array}$ & Upper \\
\hline Pre-rubric & 29.492 & 29 & .001 & 46.800 & 43.55 & 50.05 \\
$\begin{array}{c}\text { Post- } \\
\text { rubric }\end{array}$ & 21.127 & 29 & .001 & 62.867 & 56.78 & 68.95 \\
\hline
\end{tabular}

As table (5) shows, there are significant mean differences between the two means at the level $(0.05)$ as the shaded area indicates (.01). This shows that students' responses on the EPOSTL statistically differ in the beginning and at the end of the experiment. These differences favor the post assessment of the EPOSTL; therefore, the obtained results assert that 
participants' teaching competences were developed due to their use of the portfolio.

\section{Discussion}

Literature shows that using portfolios as assessment tools can promote various language areas, competencies as well as learning (Lam, 2015; Tigelaar, 2006; Van Der Shaft \& Stokking, 2008; and Bobbette, 1999). Portfolios -though time consuming- can be a useful and interesting learning experience. For instance, Cimer (2011) examined the effect of portfolios on students' learning and skills that portfolios encourage student teachers to study regularly give feedback and reflect in an ongoing process of assessment. This review agrees with the results obtained from the participants with a difference in some teaching competencies since the study examines the effect of the EPOSTL on certain teaching competencies and domains.

Though the present study utilized the paper portfolio, the obtained results agreed with studies that utilized the electronic portfolio in developing pre-service teachers' competencies as well as reflection (see Lim, Chai \& Churchill, 2011; Oakley, Pegrum \& Johnston, 2014). The obtained results assert the use of portfolios as assessment tools in teacher education programs similar to the standardized tests. Pre-service teachers need to use various student-centered assessment tools to track and reflect on their performance. These results pursue the use of portfolios in teacher education programs in various cultural contexts.

The successful use of EPOSTL in tracking and developing the didactic competences of the student teachers agree with other similar experiments in different cultural settings. For instances, Schauber (2015) utilized EPOSTL for dialogic reflection in EFL teacher education. The study revealed that the portfolio contributes valuable core knowledge to the processes of "dialogic and mentored-reflection". These results agree with the feedback given by students as discussed before. Similarly, Straková (2009) examined piloting of the EPOSTL during two distinct periods. The first was done during pre-service teacher training in 2006. Students' s task was to use the portfolio for about two semesters especially during their pre-service teacher practicum. Participants were advised to use the portfolio for better preparation for the lesson as well as to reflect on their teaching practices. The obtained results showed students' recognition of full worth of the portfolio. Students clearly found working with the portfolio is quite useful. They found that the descriptors of the portfolio are very helpful in the preparation for the lesson.

The followed steps in EPOSTL application agree with the suggested steps by Okumus \& Akalin (2015 as well as Orlova (2011) for implementing 
EPOSTL. Applying the EPOSTL in a pre-service teacher education context should follow six steps clearly defined by (Dropulja, 2015, 17): "Stage 1: The EPOSTL should be introduced to the student teachers and the tasks in the Personal statement section should be set. Stage 2: Self-assessment sections should be selected. Stage 3: Descriptors should be integrated into the course. Stage 4: Descriptors should be employed for micro-teaching tasks. Stage 5: Student teachers should use the EPOSTL during their school practicum. Stage 6: Students' opinions of the EPOSTL should be surveyed". Following the above steps may increase the significance of EPOSTL in such a context.

\section{Conclusion and implications}

In this study, the European Portfolio of Student Teachers of Languages EPOSTL was used in a pre service teacher education program during practicum. The aim of the study was to verify how effective is the EPOSTL in tracking, reflecting and developing the teaching competences of the participants. Implementing the portfolio was run over a sample of (N.30) student teachers at Hurghada Faculty of Education during their practicum (3 groups in 3 official language schools). Five areas of the portfolio were measured by the Teaching Competencies Scale (TCS) designed by the researcher. Results showed that the portfolio has positive impacts over the five areas covered in the portfolio. The feedback and results obtained from the reflections sheets by the students stressed the view that EPOSTL can be used as both a reflection sheet and as an assessment tool in the EFL teacher education context. Implications included using the EPOSTL in both pre service and in service settings. It can also be used in various stages of education from primary to secondary stages as well. The portfolio can be used for both a summative and formative assessment although the formative assessment is greater in value due the reflection practices it promotes.

\section{References:}

1. Barrett, H. (2002). Researching the Process and Outcomes of Electronic Portfolio Development in a Teacher Education Program, Paper presented at the Society for Information Technology in Teacher Education Conference, Nashville, pp. 17-23.

2. Beck, C. \& Kosnik, C. (2002). Components of a good practicum placement: Student teacher per perceptions. Teacher Education Quarterly, 29(2), pp.81-98

3. Cain, M. (2005). Developing portfolios for integrating teaching, learning and assessment, Multimedia production center, School of Education, West Indies, Trinidad and Tobago 
4. Chauber, H. (2015). Using the EPOSTL for dialogic reflection in EFL teacher education, Gist education and learning research journal, N.11, 118-137

5. Dewey, J. (1938). Experience and education, New York: Macmillan Publishing Company

6. Dineke, T. et al. (2006). Portfolio as a tool to stimulate teachers' reflections, Medical Teacher, vol. 28, No. 3, pp.277-282

7. Dropulja, J. (2015). Perspectives of the EPOSTL by student teachers of English, MA Thesis, University of Rijeka, Croatia

8. Eyers, V. (2004). Guidelines for the quality in the practicum, National Institute for Quality Teaching and School Leadership, Australia

9. Hammond, D. (2013). Developing and sustaining a high quality teacher force. Asia Society Partnership for Global Learning- Global Cities Education Network (GCEN). Retrieved: http://gelponline.org/sites/default/files/members-docyments.php

10. Holme, R. (2009). Cognitive Linguistics and Language Teaching, Basingstoke: Palgrave Macmillan

11. Hoxha, M. \& Tafani, V. (2015). European Portfolio for Student Teachers of Languages (EPOSTL): insights from student-teachers' feedback, Academic Journal of Interdisciplinary Studies, vol. 4 (3). Doi: 10.5901/ajis.2015.v4n3p71

12. Huang, J. (2012). The implementation of portfolio assessment in integrated English course, Journal of English language and literature studies, vol. 2, No 4, doi:10.5539/ells.v2n4p15

13. Karimi, F. (2014). Didactic competences among teaching staff of universities in Kenya, International Journal of Higher Education, vol. 3, No. 2, Doi: 10.5430/jjhe.v3n2p28

14. Kianna, (2018). Difference between Competence and Competency, Retrieved: http://www.differencebetween.net/language/differencebetween-competence-and-competency. Last visit \{08-02-2018\}

15. Korthagen, J. (2004). In search of the essence of a good teacher: towards a more holistic approach in teacher education, Teaching and Teacher Education, 20, pp.77-97.

16. Lam, R. (2016). Assessment as learning: examining a cycle of teaching, learning, and assessment of writing in the portfolio-based classroom. Studies in Higher Education, Vol. 41, No. 11, 1900-1917, http://dx.doi.org/10.1080/ 03075079.2014.999317

17. Lim, C., Chai, C. \& Churchill, D. (2011). A framework for developing pre-service teachers' competencies in using technologies to enhance teaching and learning, Educational Media International, Vol. 48, No. 2, 69-83 
18. Land, S. M., \& Zembal-Saul, C. (2003). Scaffolding reflection and articulation of scientific explanations in a data-rich, project-based learning environment: An investigation of progress portfolio, Educational Technology Research and Development, 51(4), 65-84

19. Newby, D. (2015). Competence and performance in learning and teaching: theories and practices. In E. Agathopoulou, T. Danavassi\& L. Efstathiadi (eds.), Selected papers on Theoretical and Applied Linguistics from ISTAL (International Symposium on Theoretical and Applied Linguistics, 24-26 April 2015). Thessaloniki: School of English, Aristotle University of Thessaloniki.

20. Newby, D.; Allan, R.; Fenner, A. B.; Jones, B.; Komorowska, H.; Soghikyan, K. (2007). European Portfolio for Student Teachers of Languages EPOSTL, Strasbourg: Council of Europe Publishing

21. Newby, D. et al. (2011). Using the European Portfolio for Student Teachers of Language, Council of Europe, Austria, ECML Publications

22. Oakley, G., Pegrum, M. \& Johnston, S. (2014). Introducing eportfolios to pre-service teachers as tools for reflection and growth: lessons learnt, Asia-Pacific Journal of Teacher Education, vol. 42, No. 1, 36-50

23. Okumus, K. \& Akalin, S. (2015). Incorporating EPOSTL (European Portfolio for Student Teachers of Languages) into Methodology Course, International Journal on New Trends in Education and Their Implications, 6(1), 84-88.

24. Orlova, N. (2011). Challenges of integrating the EPOSTL into preservice teacher training. In D. Newby, A-B. Fenner \& B. Jones (Eds.), Using the European Portfolio for Student Teachers of Languages, pp. 19-28. Strasbourg: Council of Europe Publishing.

25. Paisi, M. (2014). Dimensions of teaching staff professional competences. Social and behavioral science, vol.140 (1), pp. 924-929

26. Robinson, P. and Ellis, N.C. (eds.) (2008).Handbook of Cognitive Linguistics and Second Language Acquisition, New York: Routledge

27. Shackelford, R. L. (1996). Student portfolios: A process/product learning and assessment strategy. Technology Teacher, 55(8), 31-36

28. Strakova, Z. (2009). European portfolio for student teachers of languages and its benefits for pre-service teacher training, 3/7014/09, KEGA Project. Retrieved June 10, 2015, Retrieved from:

29. http://www.pulib.sk/web/kniznica/elpub/dokument/Kacmarova1/subo r/13.pdf

30. Strudler, N. \& Wetzel, K. (2012). Electronic portfolios in teacher education: forging a middle ground. JRTE, vol. 44, No. 2 pp. 161-173 
31. Tigelaar, H.; Dolmans, M.; Wolfhagen, P.; \& Van Der Vleuten, M. (2004). The development and validation of a framework for teaching competencies in higher education, Higher Education, 48, 253-268.

32. Tomasello, M. (2003). Constructing a Language, Cambridge, Mass.: Harvard University Press

33. Ulvik, M. \& Smith, K. (2011). What characterizes a good practicum in teacher education?EducationInquiry. vol. 2, No. 3, pp. 517-536

34. Van Der Shaft, M. \& Stokking, K. (2008). Developing and validating a design for teacher portfolio assessment, Assessment and Evaluation in Higher Education, vol. 33, No, 3, 245-262

35. Vygotsky, L. (1986). Thought and language, Cambridge, MA Thesis, MIT Press

36. Wilson, E. K. (2006). The impact of an alternative model of student teacher supervision: Views of the participants. Teaching and Teacher Education, 2 (2), pp.22-31

\section{Appendices}

\section{Appendix (1): Table \& figures}

\begin{tabular}{|c|c|}
\hline Tables & Description \\
\hline 1 & EPOSTL scope and sequence during practicum \\
\hline 2 & Descriptive Statistics \\
\hline 3 & Comparing means \\
\hline 4 & Descriptive Statistics \\
\hline 5 & Comparing means \\
\hline Figures & Description \\
\hline 1 & Figure (1) Korthagen (2004) Teacher reflection \\
\hline 2 & EPOSTL and the European Education documents \\
\hline 3 & Example descriptor from EPOSTL \\
\hline
\end{tabular}




\section{Appendix (2) Didactic competencies scale}

Core didactic competencies of pre-service English language teachers

Directions:

Kindly tick the cell that represents your views using the following rating scale.

\begin{tabular}{|c|c|c|c|c|}
\hline Poor & Fair & Good & Very Good & Excellent \\
\hline $0-20 \%$ & $21-40 \%$ & $41-60 \%$ & $61-80 \%$ & $81-100 \%$ \\
\hline
\end{tabular}

\begin{tabular}{|c|c|c|c|c|c|c|c|}
\hline \multirow[b]{2}{*}{ No } & \multirow[b]{2}{*}{ Area / competence } & \multicolumn{5}{|c|}{ Rating scale } & \multirow[b]{2}{*}{ Comments } \\
\hline & & $\begin{array}{c}\% 0- \\
20\end{array}$ & $\begin{array}{c}\% \\
21 \\
-40 \\
\end{array}$ & $\begin{array}{c}\% \\
41 \\
-60 \\
\end{array}$ & $\begin{array}{c}\% \\
61- \\
80\end{array}$ & $\begin{array}{c}\% \\
81- \\
100\end{array}$ & \\
\hline 1. & \multicolumn{7}{|c|}{ Lesson Planning } \\
\hline 1.1. & $\begin{array}{l}\text { I can formulate SMART learning } \\
\text { objectives. }\end{array}$ & & & & & & \\
\hline 1.2 . & $\begin{array}{c}\text { I can formulate learning objectives that } \\
\text { help students to reflect on their } \\
\text { learning. }\end{array}$ & & & & & & \\
\hline 1.3 & $\begin{array}{l}\text { I can apply different techniques to test } \\
\text { lesson objectives. }\end{array}$ & & & & & & \\
\hline 1.4. & $\begin{array}{c}\text { I can set objectives to the different } \\
\text { knowledge, skills and attitudes covered } \\
\text { in a lesson }\end{array}$ & & & & & & \\
\hline 1.5 & $\begin{array}{c}\text { I can involve colleagues and students in } \\
\text { the process of designing lesson } \\
\text { objectives. }\end{array}$ & & & & & & \\
\hline 1.6. & $\begin{array}{l}\text { I can accumulate learning objectives } \\
\text { next to the teacher guide. }\end{array}$ & & & & & & \\
\hline 1.7. & $\begin{array}{l}\text { I can design activities in the light of } \\
\text { lesson objectives. }\end{array}$ & & & & & & \\
\hline 1.8. & $\begin{array}{l}\text { I can set different class groupings in } \\
\text { the design of the lesson plan. }\end{array}$ & & & & & & \\
\hline 1.9. & $\begin{array}{l}\text { I can design various warm up activities } \\
\text { in the plan. }\end{array}$ & & & & & & \\
\hline 1.10 . & $\begin{array}{l}\text { I can plan various assessment } \\
\text { procedures for learning and of learning. }\end{array}$ & & & & & & \\
\hline 2. & Con & ecting & Less & & & & \\
\hline 2.1. & $\begin{array}{l}\text { I can adjust my teaching time to the } \\
\text { schedule. }\end{array}$ & & & & & & \\
\hline 2.2. & I can engage students in their learning. & & & & & & \\
\hline 2.3 & $\begin{array}{l}\text { I can use a variety of activities that } \\
\text { develop autonomy. }\end{array}$ & & & & & & \\
\hline 2.4 & $\begin{array}{l}\text { I can relate the teaching practices to the } \\
\text { levels of my students. }\end{array}$ & & & & & & \\
\hline 2.5 & $\begin{array}{c}\text { I use various assessment procedures for } \\
\text { learning and of learning in my } \\
\text { teaching. }\end{array}$ & & & & & & \\
\hline 2.6. & $\begin{array}{c}\text { I can integrate technology in my } \\
\text { teaching. }\end{array}$ & & & & & & \\
\hline 2.7 . & $\begin{array}{c}\text { I can use various resources in } \\
\text { conducting activities. }\end{array}$ & & & & & & \\
\hline 2.8 & $\begin{array}{l}\text { I can use self, peer and group activities } \\
\text { and feedbacks. }\end{array}$ & & & & & & \\
\hline
\end{tabular}




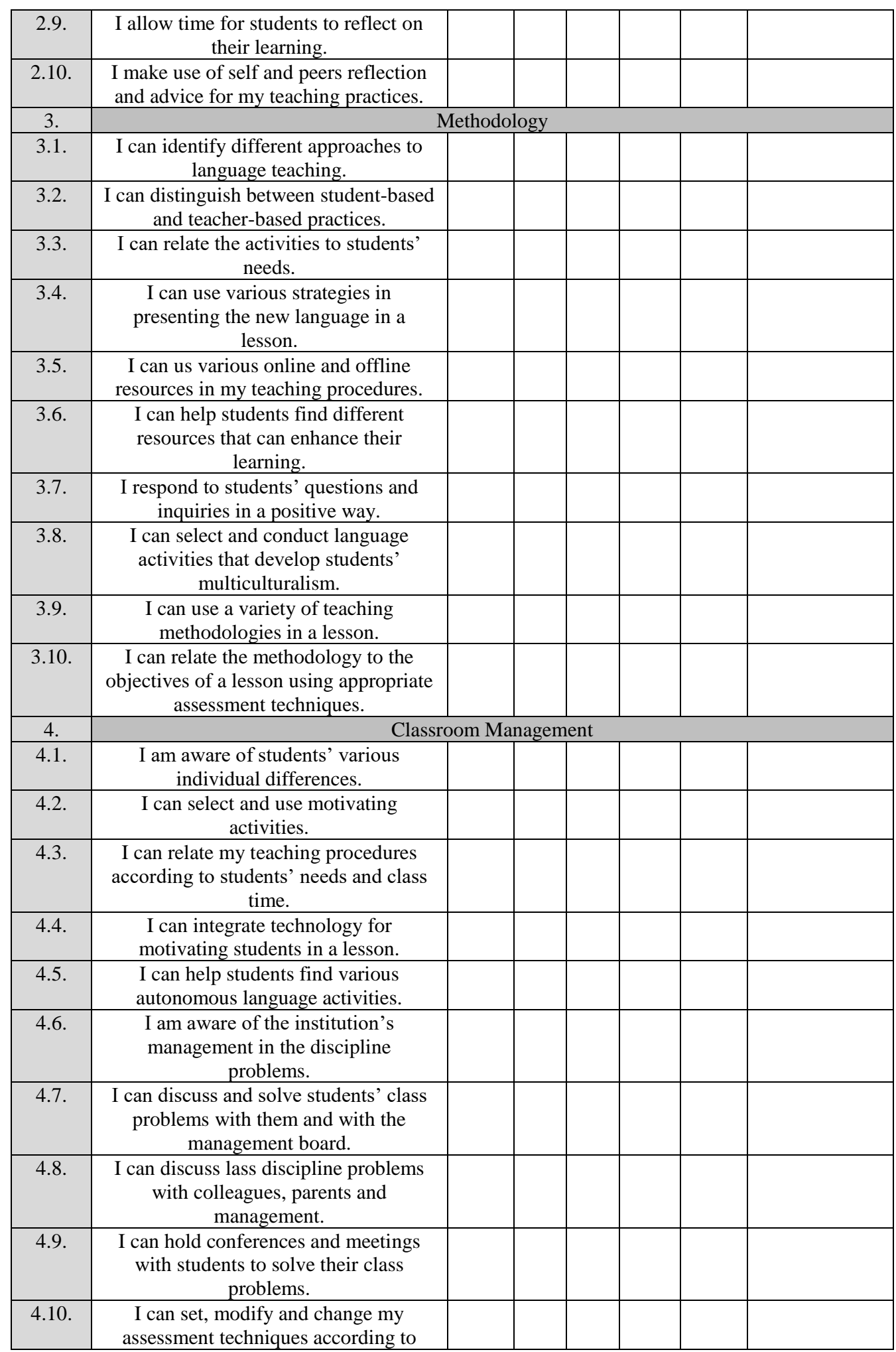




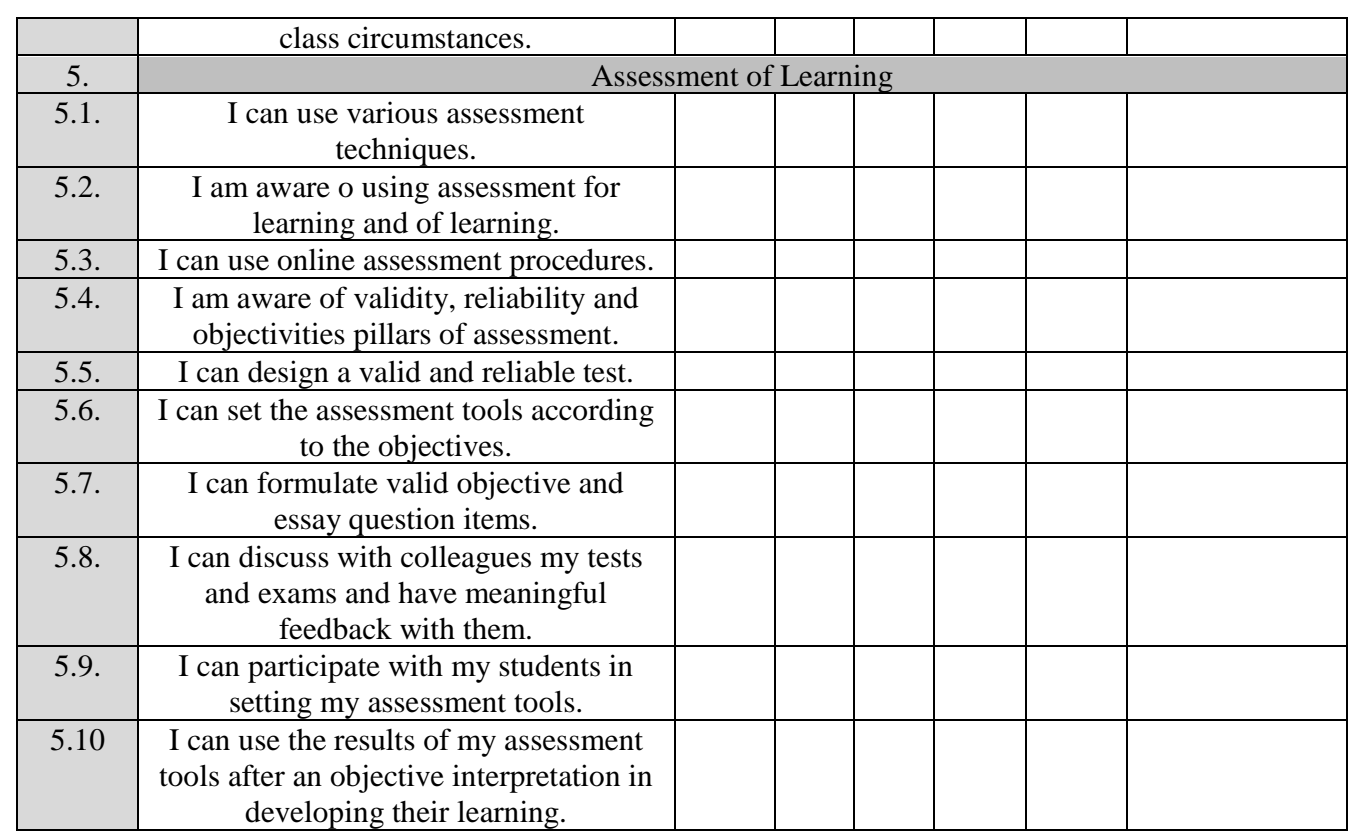

\section{Appendix (3) Scoring rubric Scoring rubric for assessing EPOSTL responses}

\begin{tabular}{|c|c|c|c|c|c|c|}
\hline \multirow[b]{2}{*}{ No } & \multirow[b]{2}{*}{ Domain } & \multirow{2}{*}{ Sub-domains } & \multicolumn{3}{|c|}{ Performance indicators } & \multirow{2}{*}{$\begin{array}{c}\text { Total } \\
\mathbf{1 0 0}\end{array}$} \\
\hline & & & $\begin{array}{c}1 \\
\text { Fair }\end{array}$ & $\begin{array}{c}2 \\
\text { Good }\end{array}$ & $\begin{array}{c}3 \\
\text { Excellent }\end{array}$ & \\
\hline \multirow{5}{*}{1} & \multirow{5}{*}{$\begin{array}{l}\text { Lesson } \\
\text { planning }\end{array}$} & $\begin{array}{l}\text { 1. The portfolio shows that the student } \\
\text { can clearly identify the learning } \\
\text { objectives. }\end{array}$ & & & & \\
\hline & & $\begin{array}{l}\text { 2. The portfolio showed evidence for } \\
\text { content mastery. }\end{array}$ & & & & \\
\hline & & $\begin{array}{l}\text { 3. The portfolio shows that student can } \\
\text { clearly define lessons organization. }\end{array}$ & & & & \\
\hline & & $\begin{array}{l}\text { 4. The portfolio included evidence for } \\
\text { various lesson plans. }\end{array}$ & & & & \\
\hline & & $\begin{array}{l}\text { 5. The portfolio provides evidence for } \\
\text { student's ability to design correct } \\
\text { objectives }\end{array}$ & & & & \\
\hline \multirow{4}{*}{2} & \multirow{4}{*}{$\begin{array}{l}\text { Conducting } \\
\text { a lesson and } \\
\text { class } \\
\text { management }\end{array}$} & $\begin{array}{l}\text { 6. The portfolio provided evidence for } \\
\text { procedural lesson presentation. }\end{array}$ & & & & \\
\hline & & $\begin{array}{l}\text { 7.The portfolio included expressed } \\
\text { situations that show interaction with } \\
\text { learners }\end{array}$ & & & & \\
\hline & & $\begin{array}{l}\text { 8. The portfolio included sufficient } \\
\text { content practices and exercises for } \\
\text { students. }\end{array}$ & & & & \\
\hline & & $\begin{array}{l}\text { 9. The portfolio included evidence for } \\
\text { effective use of classroom management } \\
\text { language. }\end{array}$ & & & & \\
\hline
\end{tabular}




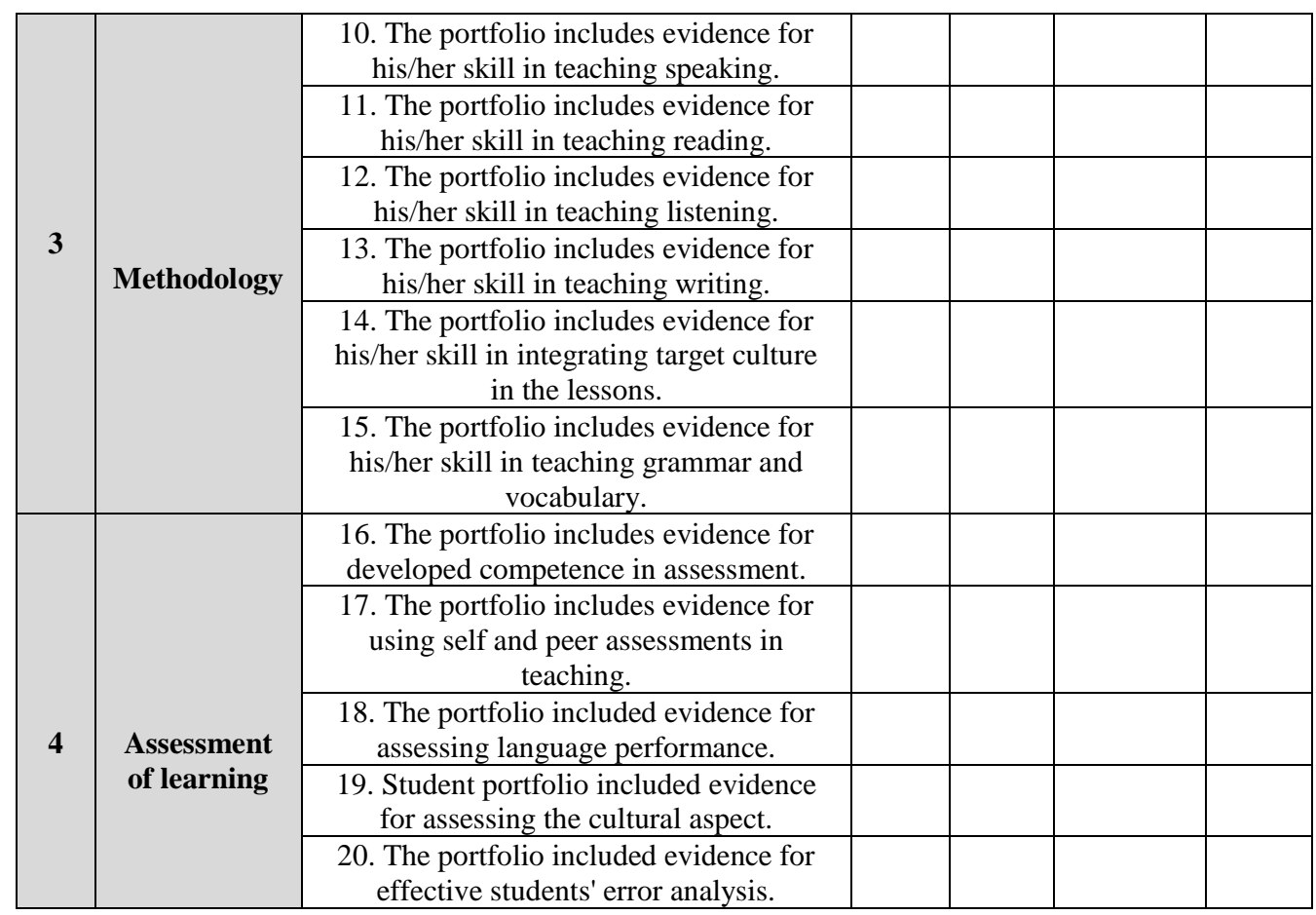

